\title{
Discovery of the Puerto Rican Crested Anole, Anolis cristatellus Duméril \& Bibron, on Trinidad
}

\author{
Renoir J. Auguste ${ }^{1,{ }^{*}}$, Kester Dass ${ }^{1}$, and Darius Baldeo' \\ 'Trinidad and Tobago Field Naturalists' Club, P.O. Box 642, Port-of-Spain, Trinidad and Tobago \\ *Corresponding author (renguste@gmail.com) \\ Date of publication: 1 November 2018. \\ Citation: Auguste RJ, Dass K, Baldeo D (2018). Discovery of the Puerto Rican Crested Anole, Anolis cristatellus Duméril \& Bibron, on Trinidad. \\ Caribbean Herpetology, 63, 1-2. \\ DOI: $10.31611 /$ ch.63
}

We report the first record of the Puerto Rican Crested Anole, Anolis cristatellus, from Trinidad and Tobago. Our report is the furthest south the species has been recorded in the wider Caribbean (CABI Invasive Species Compendium, 2018). On 19 August 2018, one of us (KD) first observed a small population of about five individuals, including an adult male (Fig. 1) near an urban area at La Romain, southwestern Trinidad (10.2498, -61.4861). One of us (DB) caught a juvenile on 26 August 2018 at the same location, and (RJA) brought it to The University of the West Indies Zoology Museum (UWIZM) at the St. Augustine Campus, Trinidad, where it was preserved in $95 \%$ ethanol and catalogued (UWIZM.2018.38).

Eight other species of Anolis have been reported from Trinidad and Tobago (Murphy et al. 2018), with six of these being introduced to the country; Anolis cristatellus represents the seventh introduced Anolis to Trinidad and Tobago. It can be easily distinguished from all other Anolis on Trinidad by the crest on the tail and body of adult males (Figure 1). Anolis cristatellus has been introduced to countries outside of its native range through human facilitations, such as the transporting of ornamental potted plants (CABI Invasive Species Compendium 2018). The area where we observed the anoles was near the coast, with industrial development nearby. There are two subspecies of Anolis cristatellus and all of those that have been introduced outside of their native range are apparently A. c. cristatellus (Henderson \& Powell 2009).

Anolis cristatellus has the potential to compete with and displace native and other introduced Anolis species on Trinidad. They occur in both urban and forested areas in their native range and have various attributes that would contribute to being a successful invasive (CABI Invasive Species Compendium 2018). Therefore, the species is considered an ideal organism for studying invasion and adaptation. Tracking and reporting on their distribution can further contribute to knowledge on

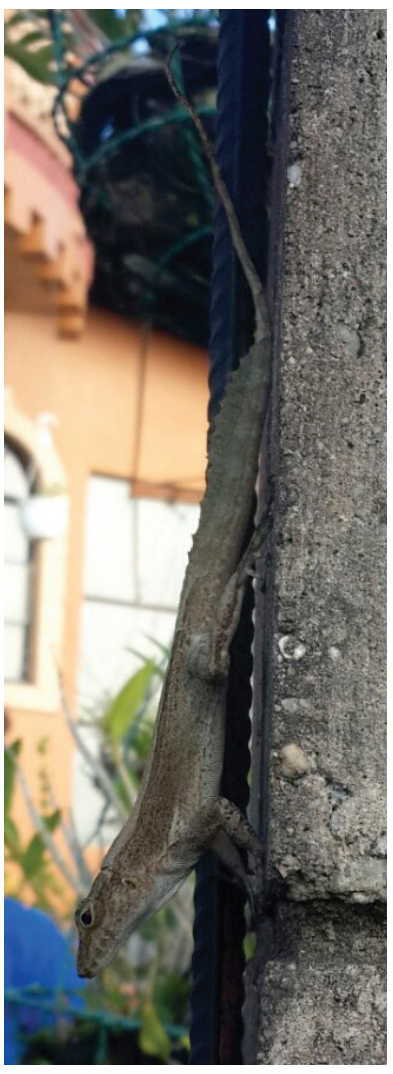

Figure 1. A male Anolis cristatellus perching on a post in southwestern Trinidad. Photo by Kester Dass. its invasive and adaptive capabilities.

\section{Acknowledgments}

We thank John C. Murphy (Field Museum of Natural History) and Jonathan B. Losos (Washington University) for assistance in identifying the species. 


\section{References}

CABI Invasive Species Compendium (2018) Anolis cristatellus. Available online at https://www.cabi.org/isc/datasheet/93810. Accessed 24 September 2018.

Henderson RW, Powell R (2009) Natural history of West Indian reptiles and amphibians. (University Press of Florida, Gainesville).

Murphy JC, Downie JR, Smith JM, Livingstone SR, Mohammed RS, Auguste RJ, Lehtinen RM, Eyre M, Sewlal JN, Noriega N, Casper GS, Anton T, Thomas RA, Rutherford MG, Braswell AL, Jowers MJ (2018) A field guide to the amphibians and reptiles of Trinidad and Tobago (Trinidad and Tobago Field Naturalists' Club, Port of Spain). 